\title{
A irredutibilidade da intenção como input do significado humorístico na piada
}

\section{The non-reductive intention as input of the humorous meaning in jokes}

Sebastião Lourenço dos Santos ${ }^{1}$

Doutor em Estudos Linguísticos. Professor Adjunto do Curso de Letras e do Programa de Mestrado em Linguagem, Identidade Subjetividade da Universidade Estadual $d e$ Ponta Grossa. Desenvolve pesquisa sobre linguagem, cognição e relevância. Autor do livro O enigma da piada: convergencias teóricas e emergência pragmática (Ed.
RESUMO: Em uma conversação espontânea, em que os interlocutores negociam interpretações voláteis, que se dissolvem tão logo os enunciados são pronunciados, a intenção de quem comunica uma informação tem uma implicação muito grande na contextualização do significado. Em uma piada, que é uma conversação não-espontânea, o narrador tem a liberdade de manipular a história intencionalmente, de modo a produzir menos ou mais expectativas sobre o desfecho da narrativa. 0 objetivo deste artigo é descrever como se processa a interpretação do significado humorístico implicitamente manifesto na piada. A hipótese é de que, na piada, a intenção de narrador deve confirmar ou refutar um conhecimento ou uma crença do ouvinte, tal que a interpretação do significado, se bem sucedida, gere o riso. A base teórica que fundamenta o estudo segue a perspectiva pragmática relevantista (SPERBER; WILSON, 1986).

PALAVRAS-CHAVE: Intenção; Interpretação; Significado; Inferência.

ABSTRACT: In a spontaneous conversation, in which the interlocutors negotiate changeable interpretations, which in their turn dissolve as soon as the statements are pronounced, the intention of the one who conveys information has a great implication on the contextualization of meaning. In a non-spontaneous conversation as a joke, the teller has the autonomy to intentionally manipulate the story in order to produce smaller or greater expectations on the conclusion of it. The aim of this article is to describe the interpretation process of the humoristic meaning implicitly manifest in a joke. The hypothesis is that in a joke the teller's intention must confirm or refute a piece of knowledge or creed sustained by the hearer in a way that the interpretation of the meaning, once successful, provokes laughter. The theoretical basis for this study follows the relevance-based pragmatic perspective (SPERBER; WILSON, 1986).

KEYwORDS: Intention; Interpretation; Meaning; Inference. 


\section{Introdução}

$\mathrm{E}^{\mathrm{n}}$ m Relevance: comunication and cognition, Dan Sperber e Deirdre Wilson (1986) defendem a ideia de que o que distingue o tradicional modelo semiótico de comunicação codificada do modelo inferencial proposto por Grice (1975) é o estabelecimento de uma propriedade psicocognitiva mínima que comanda a comunicação entre os indivíduos: a intenção. Contudo, na interação conversacional, para que haja comunicação, é necessário o estabelecimento de duas outras propriedades à intenção: a) que ela seja explícita e b) que seja reconhecida pelo(s) interlocutor(es).

O modelo pragmático proposto pelos autores para descrever os procedimentos cognitivos de interpretação humana ficou conhecido por Teoria da Relevância (doravante TR). Na perspectiva da TR, a comunicação humana é inerente a um processo interacional no qual estão envolvidos dois mecanismos, o falante e o ouvinte; e o falante, ao produzir um enunciado, tem a intenção manifesta de levar o ouvinte a desenvolver pensamentos muito próximos às suas representações de mundo. Nessa perspectiva, como ambos os interlocutores são altamente idiossincráticos, seus pensamentos são manifestos por representações conceptuais do mundo real de cada um individualmente. No caso da piada, a questão que se levanta é: dado que a intenção do falante não pode ser linguisticamente decodificada, apenas cognitivamente inferida pelo ouvinte, o que é que os participantes de um intercâmbio humorístico comunicam quando se comunicam? Mais: quais são as bases inferenciais linguístico-cognitivas que fundamentam e comandam a comunicação humorística?

Conforme Sperber e Wilson, a comunicação verbal entre os indivíduos é possível porque a cognição humana tende a dirigir-se à relevância ótima, conceito que Grice deixou vago em seus postulados conversacionais de 1975. De acordo os autores, a relevância é uma propriedade psicológica que faz com que uma informação veiculada a um enunciado valha a pena ser processada em termos de esforço e efeito cognitivo de processamento, porque, dadas as especificidades contextuais, a interpretação desse enunciado modifica e reorganiza suposições factuais (pensamentos) disponíveis na mente do ouvinte. Segundo a TR, o trabalho de interpretação humana é comandado pelo "Princípio Cognitivo de Relevância", princípio segundo o qual a atenção do ouvinte e seus recursos cognitivos de processamento estão dirigidos para a maximização daquelas informações que lhe são (mais) relevantes em um dado contexto.

Seguindo a linha relevantista proposta por Sperber e Wilson (1986), propomos, neste estudo, especular que, na interpretação da piada, as informações mais relevantes ao ouvinte deverão ser aquelas que causam maior efeito humorístico e exigem menor esforço de processamento. Com essa postura, assumimos que, na piada, a intenção do narrador é otimamente relevante ao ouvinte se, e apenas se, o significado humorístico da história narrada é suficientemente relevante para valer a pena ser processado pelo ouvinte, porque é o mais compatível com suas expectativas e preferências. Porém, se na interpretação humorística da piada houver algum precedente psico-cognitivo, seja de ordem linguístico-discursivo ou sociocultural, que fira as expectativas do significado do ouvinte, o processamento dedutivoinferencial não cessa, mas a piada como gênero textual perde seu caráter de humor (SANTOS, 2014, p. 187).

Alinhamos o estudo do humor da piada aos conceitos da teoria relevantista, porque, diferentemente de muitas teorias linguístico-comunicativas tradicionais, comunicar humoristicamente não implica necessariamente transmitir uma informação, mas, segundo a perspectiva da TR, comunicar a intenção de comunicar uma informação. Essa ideia tem como base duas hipóteses mais gerais da teoria: a) uma intenção comunicativa - decisão de estabelecer contato com outros seres humanos; e b) uma intenção 
informativa - decisão de comunicar uma informação nova. Nos próximos parágrafos, nos ocuparemos de descrever como o ouvinte interpreta o humor a partir da intenção do falante.

\section{Conceituando a intenção}

De acordo com a TR, os enunciados produzidos em intercâmbios conversacionais perfazem, entre outras coisas, a conexão entre os pensamentos dos indivíduos e o mundo real (ou um mundo provável). A manifestação social de uma elocução é uma espécie de núcleo comum do significado que é partilhado por todas as elocuções que nela se baseiam. No entanto, as elocuções não são utilizadas somente para externar pensamentos humanos, mas revelam atitudes sobre estados mentais (anseios, desejos, frustrações, alegrias, ambições, etc.) dos falantes e sua relação com o pensamento expresso em tais elocuções. A pressuposição que se encontra por trás desses argumentos é que os interlocutores estabelecem certos padrões de veracidade e de valor informativo às elocuções de modo que só comunicam informações que se coadunam a esses padrões.

Para explicar como o significado humorístico se processa na piada, nosso ponto de partida é o artigo Meaning, de Grice (1957). Ao diferenciar o significado natural (manchas vermelhas na pele indicam sarampo) do nãonatural, o autor caracteriza o segundo em termos da intenção do falante com o seguinte postulado: $\mathrm{O}$ falante quer dizer não naturalmente algo com x é (mais ou menos) equivalente a "o falante tem a intenção de que o enunciado x produza algum efeito em um ouvinte pelo reconhecimento da sua intenção". (GRICE, 1957).

Em Meaning, Grice distingue três tipos de significado não naturais: o significado da sentença, o significado da elocução e o significado do falante, que remete à intenção comunicativa que se deseja expressar. Nessa acepção, "x significa algo" equivale a "o falante quer dizer não naturalmente algo com x". Embora o aporte teórico de Meaning parta da análise do significado do falante para o significado da sentença e da palavra, essa perspectiva carece de configurações lógico-semânticas mais gerais, pelo fato de que impõe a indução da crença do falante sobre o ouvinte. Contudo, essa configuração teórica, que reconhece a intenção do falante como elemento chave da interpretação do significado representa, em linhas gerais, os passos cruciais para a descrição de uma teoria pragmática da comunicação humana.

Meaning, no entanto, não era suficientemente eficaz para o tratamento de questões mais complexas que envolvem a linguagem natural e foi objeto de muitas controvérsias, críticas e revisões por parte dos estudiosos da linguagem. Uma revisão bastante relevante aos filósofos da linguagem foi proposta por Strawson em 1964, e apresentada por Sperber e Wilson em 1986, conforme segue:

[...] Para significar alguma coisa através de uma elocução $x$, um indivíduo deve ter a intenção de:

a) a elocução $x$ produzida por F produzir um certa resposta $r$ num certo receptor $R$;

b) a intenção (a) de $F$ ser reconhecida por $R$;

c) o reconhecimento por $R$ da intenção (a) de $F$ funcionar como parte, pelo menos, da razão de $R$ dar a resposta $r$ de $R$ (SPERBER; WILSON, 1986, p. 63-64).

Da releitura de Strawson, adaptando o conceito de receptor $R$ para ouvinte 0 , podemos verificar que a proposta de Grice se imbrica em três subintenções: a) que o enunciado " $x$ " produza uma resposta " $r$ " no ouvinte " $O$ "; b) que "O" reconheça a intenção (a) do falante " $F$ "; c) que o reconhecimento de "O" da intenção (a) de " $F$ " funcionar como, pelo menos, parte da razão de "O" dar a resposta " $r$ ". 
Partindo dessas premissas, Sperber e Wilson (1986) consideram que a comunicação humana pode (mas não necessariamente) ser bem sucedida se pelo menos as condições "a" e "b" anteriores forem satisfeitas. Os autores chamam a primeira de intenção "informativa" e a segunda de intenção "comunicativa" de um enunciado.

Para Sperber e Wilson, o reconhecimento pelo ouvinte da intenção do falante é um empenho cognitivo vulgar, já que a atribuição de significado aos enunciados é uma propriedade da cognição e das interações inferenciais em um contexto. $\mathrm{O}$ contexto, por sua vez, é um construto mental formado por um subconjunto de suposições factuais (pensamentos) que os interlocutores têm do mundo, suposições essas que afetam a interpretação das elocuções, porque acrescentam algum conhecimento ao conjunto de contextos potenciais dos indivíduos.

Santos (2013) conceitua o contexto conversacional como:

[...] o ambiente abstrato, dinâmico, vivo, comum, mas não idêntico, a dois ou mais participantes de um intercâmbio conversacional, que de acordo com as contingências circunstanciais, orienta, restringe ou amplia a tomada de decisões dos interlocutores, enriquecendo ou saturando a linguagem humana com informações linguísticas e não linguísticas relevantes à produção e à interpretação de significados comunicados e inferidos conversacionalmente. (SANTOS, 2013, p. 707-708)

Como o contexto utilizado na interpretação conversacional contém, geralmente, informações derivadas de contextos imediatamente anteriores, cada nova elocução exige um contexto diferente, embora se alimente das mesmas referências e das mesmas capacidades inferenciais de que se alimentaram as elocuções anteriores. A única maneira de se poder ter certeza de que na interação conversacional não ocorrerá nenhum equívoco de interpretação é garantir que o contexto mental do ouvinte fosse sempre idêntico ao visualizado pelo falante no momento do enunciado. No entanto: será que é possível ao falante e ao ouvinte distinguirem os pensamentos que partilham entre si daqueles que não partilham?

Para que o ouvinte faça uma interpretação ótima do significado de um enunciado - aquele que o falante tem a intenção manifesta de comunicar cada pormenor de informação contextual utilizada na comunicação tem de ser não só conhecido pelo falante, mas conhecido mutuamente pelo ouvinte. Contudo, na perspectiva relevantista, se uma pessoa não sabe se tem o conhecimento mútuo de algo com alguém, então não o tem. 0 conhecimento mútuo tem de ser sentido e reconhecido como certo, ou então não existe; e como nunca pode ser sentido e reconhecido como certo por ambos os interlocutores, o conhecimento mútuo entre indivíduos não existe. $\mathrm{O}$ que existe, devido à idiossincrasia dos interlocutores, são conhecimentos individuais sobre referentes, eventos ou estados de coisas comuns, e "conhecimentos compartilhados", conceito amplamente aceito e divulgado por muitas teorias linguísticas.

Mas o que é o significado em uma conversação? O paradigma geralmente aceito pelas teorias linguísticas tradicionais prediz que o significado é aquilo que se encontra explicitamente expresso em uma sentença. A comunicação verbal de um significado explícito é, então, tomada como modelo de comunicação geral. No entanto, essa espécie de comunicação explícita que se consegue por meio da utilização da linguagem verbal não é um caso típico, mas um caso limite, porque, se o significado for reduzido ao modelo linguístico apenas, dá origem a distorções teóricas e empíricas.

Existe, por certo, na comunicação verbalizada uma codificação e uma decodificação linguística, mas o significado que o falante pretende intencionalmente comunicar fica aquém do código linguístico - este é apenas uma parcela da evidência sobre as intenções do falante e auxilia o ouvinte a inferir o que o falante quer dizer. A concepção base que norteia a TR é que, em um conjunto de suposições (pensamentos), aquilo que é comunicado 
por uma elocução (declarativa, por exemplo) é o significado explicitamente expresso por uma suposição. As outras, se houver, são comunicadas implicitamente, ou implicadas. Em um enunciado, o que diferencia o seu conteúdo explícito da implicatura é: enquanto o conteúdo explícito pode ser decodificado linguisticamente, a implicatura só pode ser inferida ostensivamente.

No modelo ostensivo-inferencial relevantista proposto por Sperber e Wilson, portanto, a comunicação humorística da piada seria feita em dois processos: pela pessoa que comunica, ao fornecer evidências de suas intenções, e pelo ouvinte, ao inferir as intenções do falante a partir dessas evidências fornecidas. Em efeito, na interpretação da piada, a intenção do falante será sempre implicada, isto é, o ouvinte tem de inferi-la a partir das evidências apresentadas pelo falante precisamente para esse fim.

\section{A piada prototípica}

Quando alguém ouve uma piada e ri dela não imagina que, no processo de interpretação, nem todas as suposições geradas pela mente alcançam o mesmo grau de relevância, posto que cognitivamente as suposições organizam-se em um continuum de maior a menor probabilidade. Como o Princípio Cognitivo de Relevância se assenta na hipótese de que o ouvinte tende a prestar atenção naquilo que mais lhe interessa, na interpretação da piada muitas informações só são tratadas num primeiro nível de processamento. Por conseguinte, se a atenção do ouvinte voltar-se para os inputs informativos com predisposição à maior relevância - aqueles que causam maior efeito e requerem menor esforço de processamento a probabilidade de o ouvinte obter êxito na interpretação humorística é tanto maior quanto o grau de confiança que ele tem de julgar as suposições geradas, como prováveis ou possivelmente verdadeiras.
Na perspectiva psicológica, a sequencialidade, a linearidade e o punchline da piada (sua guinada linguístico-cognitiva) evoluem sob a ordem de alguns elementos internos à narração, elementos que são responsáveis pelo concatenamento do material linguístico com as representações culturalmente construídas nas e pelas inferências e implicaturas dos interlocutores, tais como crenças, convenções, valores, comportamento, etc. Textualmente, no entanto, a estrutura da piada se organiza na relação conjunta de elementos linguísticos que subscrevem o texto narrativo, tais como personagens, tempo, tema, história, etc. Quais seriam, então, os elementos estruturais da narração humorística?

Emediato (2004) descreve que a narrativa clássica - o modelo narrativo tradicionalmente conhecido na linguística textual - é estruturada por quatro estágios, a saber:

- A exposição, que desempenha um papel de introdução da narrativa, apresentando os personagens, caracterizando-os, envolvendo-os em uma ou outra ação, construindo relações entre eles.

- A complicação, que desenvolve as ações, envolvendo-as em conflitos, criando obstáculos para os personagens, estabelecendo contrastes e confrontos entre os diversos personagens.

- O clímax, que constitui essencialmente o ponto limite do conflito e da complicação, ponto que requer finalização e conclusão, ponto gerador de angústia e expectativa de desfecho.

- O desfecho, que justamente sinaliza o alívio para os personagens e para o leitor, momento de conclusão e finalização, propondo a moral da história sem a qual todo conjunto de ações narrativas perde fundamento e razão de ser (EMEDIATO, 2004, p. 153).

Como a piada é um gênero textual muito antigo, manifesto essencialmente na oralidade com o intuito de subverter a ordem de um estado de mundo (SANTOS, 2014, p. 81), é de se pressupor que ela se coadune com a estrutura da narrativa clássica, tal como a descrita por Emediato. Vejamos como essa 
ideia de organização narrativa ocorre na piada. Tomemos a piada a seguir como exemplo.

\section{Piada 1.}

Na sala de aula, a professora escorrega e leva o maior tombo. Na queda, seu vestido sobe até a cintura. Silêncio sepulcral. Ela levanta-se rapidamente e interroga os alunos:

- O que você viu quando eu caí? - pergunta ela ao Pedrinho.

- Ah, eu vi seu joelho, professora.

- Você está uma semana suspenso! Pode sair.

- E você Juquinha, o que foi que viu quando eu caí?

- Ah professora, eu vi suas coxas.

- Um mês de suspensão para você. Pode sair.

- E você, Joãozinho, o que foi que viu quando eu caí?

O menino recolhe seu material, põe todo na mala e diz:

- Bom, turma, até o ano que vem!!!

Compulsoriamente, o esquema estrutural dessa piada é o seguinte:

exposição: a narração ambientada na caracterização da sala de aula, a interação da professora com os alunos.

complicação: conflito gerado pela queda e posição que a professora cai.

clímax: interrogatório sequencial da professora aos alunos Pedrinho, Juquinha e, claro, ao Joãozinho, sobre a visão que tiveram dela no chão.

desfecho: enunciado de despedida do Joãozinho que sintetiza que o que ele viu é, implicitamente, motivo de reprovação de ano.

\section{Vejamos outro exemplo:}

Piada 2.

O dentista do hospício atende um interno que havia extraído um dente no dia anterior:

- E então, o seu dente parou de doer?

- Sei lá, o senhor ficou com ele!

Então temos o seguinte esquema para a piada:

exposição: a narração ambientada no hospício apresenta os personagens dentista e interno.

complicação: a extração no dia anterior do dente do interno.

clímax: questionamento do dentista sobre a dor de dente que, no dia anterior, sentia o interno.

desfecho: enunciado do interno informando que ele não pode opinar sobre a "dor do dente" já que o dente não está mais com ele.

Veja que a organização estrutural da narração apresentada por Emediato (2004) exige do texto clássico uma propriedade linguística invariável: a narração em terceira pessoa. Então, a piada como gênero narrativo, tal como proposto neste artigo, não permite experimentos narrativos pósmodernos, porque, nestes paradigmas textuais, interessa muito mais a elaboração cognitivo-emotiva da ação intersubjetiva inerente ao texto, ao nonsense, do que a dinamicidade, a linearidade e progressão sequencial da narração tradicional. Seria difícil, portanto, a análise piadística sob a ótica de um texto contemporâneo que explore a "anarquia formal" - estilhaçamento da sintaxe - em que não aparecem os elementos coesivos da narrativa tradicional. 
De acordo com Gil (1998, p. 298), a piada também se caracteriza pela brevidade das ações e pela exigência de um refinado sentimento de economia de palavras, pois, sendo longa, concederia um maior espaço ao narrador, o que demandaria um gasto maior de tempo para descrever as ações e para contar o enredo, desviando, assim, a atenção do ouvinte. Além disso, a piada raramente dispensa o diálogo. No entanto, a sequência da trama, a evolução dos personagens, a ordem em que os fatos vão sendo narrados, a estruturação dos principais elementos da narrativa, ao progredirem linearmente, exigem que as ações inerentes à complicação dos confrontos e conflitos se repitam um certo número de vezes, de forma a conduzir o ouvinte a desempenhar um papel de co-autor no processamento das informações.

Geralmente, mas não é regra, o procedimento mais tradicional aplicado à piada é a sequência se repetir por três vezes, condição que permite ao ouvinte recorrer às inferências indutivas, que servirão de premissas básicas ao sistema dedutivo-inferencial que trabalha com regras pragmáticas simples e complexas. Porém, o número de vezes que a sequência se repete, ainda que não seja obrigatório fixar-se em três, deve ser tal que não comprometa o processamento das regras dedutivo-inferenciais.

\section{A intenção humorística}

Para Muniz (2004, p. 26), a intenção do narrador da piada é ludibriar o ouvinte, despistá-lo, brincar com os possíveis efeitos de significado que a narração pode suscitar, levando o ouvinte a construir várias interpretações para em seguida impedir-lhe algumas, até que, ao final, apenas um significado seja levado em conta e gere humor. Cognitivamente, no entanto, uma piada se diferencia de uma conversa espontânea pelo grau de imprevisibilidade do(s) significado(s) que a conversa improvisada possibilita em oposição ao grau de previsibilidade do(s) significado(s) da piada. O conceito "conversa espontânea" vem reforçar os conceitos relevantistas de intenção comunicativa e informativa do narrador (o contador) da piada sobre um texto elaborado com anterioridade - o contador da piada já conhece de antemão a sequência narrativa da história, o comportamento psicológico dos personagens, a ação inerente a cada um deles, o deslocamento espaço-temporal da narração e o desfecho da história (YUS RAMOS, 1996, p. 502).

Além disso, na conversa espontânea há um intercâmbio de informações novas e velhas entre os interlocutores, os quais, movidos por intenções comunicativas e informativas distintas, se alternam entre turnos conversacionais, na busca de uma harmonização do Princípio de Cooperação (GRICE, 1975) e de preservação de face muitas vezes conflituosa. Tanto na conversa espontânea quanto na piada, como o intercâmbio verbal ocorre sob muitos princípios, alguns linguísticos, outros cognitivos, outros socioculturais, o narrador e o ouvinte criam, reforçam ou recriam expectativas de significados que decorrem de processos de interpretação que podem ser, ou estar, mais ou menos salientes e/ou mais ou menos explícitos no texto. Enquanto na conversa espontânea a intenção, tanto do locutor quanto do interlocutor, depende da negociabilidade contextual do contrato comunicativo, na piada o contrato comunicativo é intencionalmente orientado, pela ostensão do narrador, para a criação de um efeito humorístico.

Partindo dessa premissa, se retomarmos a ideia inicial de Grice sobre intenção e a aplicarmos à interpretação da piada, seguindo o modelo ampliado por Strawson (1964), teremos uma generalização tal que pode lançar alguma luz sobre a intenção humorística da piada. Consideremos que, na piada:

a) o narrador "N" tem a intenção "I" de tornar manifesto "X"

b) ao tornar manifesto " $\mathrm{x}$ ", "N" tenciona causar um efeito " $E$ " no ambiente cognitivo do ouvinte "O". 
c) o ouvinte "O" deve reconhecer a intenção "I" do narrador " $\mathrm{N}$ ";

d) o reconhecimento por "O" da intenção manifesta "I" de "N" funciona, pelo menos, como parte da razão de " 0 " interpretar " $\mathrm{x}$ ".

Veja que os pressupostos da Teoria da Relevância se ajustam à interpretação da piada, uma vez que nesta o objetivo principal do narrador é causar intencionalmente uma modificação, não nos pensamentos do interlocutor, mas no seu ambiente cognitivo, mais especificamente em seu conhecimento de mundo. Como a intenção do contador da piada é fazer o ouvinte rir, ele (o narrador da piada) também gera expectativas de que o ouvinte "entenda" a piada.

No entanto, os efeitos cognitivos reais de uma piada sobre o ambiente cognitivo do ouvinte - o entendimento, a interpretação e o riso - são previsíveis apenas em parte, haja vista o grande número de variáveis linguísticas e não linguísticas - cognitivas e socioculturais - que (inter) atuam cognitivamente no processo de interpretação humorístico humano. A precisão ou imprecisão da interpretação da piada também decorre, além dos fatores linguísticos e socioculturais, da capacidade cognitivo-dedutiva tanto do narrador quanto do ouvinte. Santos (2014) ressalta que a capacidade cognitiva do processamento humorístico é uma relação da capacidade de representação dos indivíduos, que está atrelada ao ambiente cognitivo e ao contexto. Em efeito,

Sperber e Wilson consideram o contexto não como algo restrito ao ambiente físico do mundo real ou ao cotexto, mas às expectativas que se tornam acessíveis no processamento das informações, tais como hipóteses científicas, crenças culturais, valores e saberes dos interlocutores, ou seja, para a TR o contexto é um construto psicológico, um subconjunto de suposições do ouvinte sobre 0 mundo. Os autores propõem o termo "ambiente cognitivo", cujo conceito é um paralelo ao entorno espaço-temporal que acessamos pelos sentidos, ou seja, com o qual percebemos o mundo. 0 ambiente cognitivo, então, é um conjunto de "representações" mentais aceitas como verdadeiras, ou como provavelmente verdadeiras, e ao qual os indivíduos recorrem no instante do processamento de uma informação nova. No entanto, os próprios autores contestam essa hipótese, pois cada nova informação determina um novo contexto. Nesse caso, o discurso anterior serve de contexto para o enunciado que se está produzindo em determinado momento, já que a implicação contextual é, pois, uma síntese da velha e da nova informação, que constituem premissas numa implicação sintética. (SANTOS, 2014, p. 87).

Para entendermos como isso ocorre, vejamos a seguinte piada:

Piada 3.

Duas secretárias falam do executivo que acaba de entrar em sua sala:

S1: - Como ele se veste bem, não acha?

S2: - Sim... e rápido.

Quanto à análise e explicação da piada, a partir dos elementos linguísticoestruturais, as teorias linguísticas tradicionais fornecem bons argumentos sobre os detalhes e possibilidades de interpretação. Quanto à intenção pragmática, tanto do narrador interno, ou do contador da piada, quanto do ouvinte, essa piada pode ser descrita basicamente como segue:

a) o narrador "N" tem a intenção "I" de tornar manifesto "x";

b) com isso, o narrador " $\mathrm{N}$ " tenciona causar um efeito " $\mathrm{E}$ " no ambiente cognitivo do ouvinte " $\mathrm{O}$ " de maneira que " $\mathrm{O}$ " interprete " $\mathrm{x}$ ";

c) para tanto, "N" cria expectativas de que " $\mathrm{O}$ " reconheça "I" e de que, ao reconhecer "I", "O" interprete " $\mathrm{x}$ ";

d) por sua vez, "O" cria expectativas sobre a manifestabilidade da intenção "I" do narrador "N" sobre " $\mathrm{x}$ ":

e) "O" espera reconhecer/interpretar " $\mathrm{x}$ ". 
Mas qual é a intenção informativa "I" de ambas as secretárias e o significado " $x$ " na piada acima? Primeiramente, é preciso esclarecer que a narração dessa piada implica três níveis processuais de intenção: a) a do contador da piada, ao qual nominamos narrador externo - que tenciona provocar o riso; b) a do ouvinte/leitor " $\mathrm{O}$ ", que busca entender e interpretála; c) e a do narrador e dos personagens internos à narrativa - cuja ação/ reação determina cognitivamente a intenção do narrador externo, e em consequência o humor na piada. $\mathrm{O}$ esquema procedural sobre intenção que descrevemos acima se coaduna perfeitamente com a intenção do narrador externo da piada. O que falta explicar é como ocorre o processo dedutivoinferencial dos personagens internos à piada, isto é, como se processam as intenções informativas das duas secretárias.

De acordo com nossa proposta, a intenção informativa "I" da secretária S1 era tornar manifesto, ou mais manifesto, para sua companheira de trabalho (S2) o significado " $\mathrm{x}$ " de que ela (S1) percebeu como o executivo se veste elegantemente. Pelo Princípio de Relevância, a intenção "I" implicada no enunciado da secretária S1 sobre o quão elegante se veste o executivo contém a suposição/significado " $x$ " mais relevante que S2 deve inferir sem grandes problemas, isto é, a suposição que causa maior efeito e exige menor esforço mental de processamento de S2.

Já a intenção informativa "I" que o narrador "N" tenciona tornar manifesta ao ouvinte "O" sobre e elocução da secretária S2 é construída sobre alguns elementos linguísticos e muitos fatores pragmáticos discursivo-contextuais tácitos à elocução que fecha a narrativa. $\mathrm{O}$ reconhecimento pelo ouvinte "O" da intenção "I" do narrador "N" sobre o significado " $\mathrm{x}$ " comunicado por S2 implica que, dentre um conjunto de suposições válidas geradas pelo final da narração, o sistema dedutivo-cognitivo do ouvinte " $O$ " deve eleger a suposição que lhe parece mais relevante produzida pelo final da piada, ou seja, após ouvir a elocução final de S2, o ouvinte "O" deve inter- pretar a intenção informativa "I" comunicada por "N" sobre o significado " $\mathrm{x}$ ".

Na perspectiva pragmática, a intenção informativa "I" contida na elocução final de S2 pode, então, ser explicada da seguinte maneira: além de concordar com S1 sobre o vestuário do executivo, S2 também já transou com ele. Todavia, ter transado com o executivo não é o significado "x" que S2 tem a intenção "I" de tornar manifesto a S1; ter transado com o executivo é apenas uma parte da intenção "I" de S2. A réplica de S2 à S1 fornece ao ouvinte "O" informações tácitas de que além de $\mathrm{S} 2$ ter transado com o executivo, a transa se deu ou no próprio local de trabalho (talvez no banheiro) ou em um lugar próximo ao local de trabalho, e que a transa fora bem rápida e que, quiçá devido à urgência dos afazeres laborais dos dois ou o receio de serem surpreendidos, o executivo teve que se vestir depressa. S2 fornece, portanto, evidências tácitas, tanto linguísticas quanto pragmáticas, de que, além de concordar com sua colega S1, ela (S2) admira a rapidez com que o executivo se veste após uma "rapidinha".

Esse é o significado " $\mathrm{x}$ " implicitado na intenção informativa "I" de "N" e comunicado na elocução final de S2, e é a esse " $x$ " que o ouvinte deve chegar para rir da piada. Isso tudo é " $\mathrm{x}$ ". E tanto S1 quanto o ouvinte da piada devem reconhecer esse " $x$ " porque, em tese, essa é a suposição mais relevante que $o$ narrador "N" tenciona tornar manifesta ao ouvinte "O", pois "N" acredita que esta é a suposição que causa maior efeito cognitivo e exige menor esforço de processamento no ouvinte " $O$ ". É o que chamamos "efeito contextual". O efeito contextual se produz quando um conhecimento existente é, de algum modo, modificado pela nova informação que é processada pelo sistema cognitivo. Essa modificação desemboca no fortalecimento, enfraquecimento ou abandono de suposições prévias do ouvinte. Em geral, quanto maior for o número de efeitos criados por uma suposição, maior é a relevância da informação processada. 
Vejamos outro exemplo:

Piada 4.

O guarda faz sinal para o motorista parar, na rua. 0 motorista abaixa o vidro:

- O que houve seu guarda?

- Não sei se o senhor soube. Sequestraram nosso prefeito. Os sequestradores dizem que se não pagarmos o resgate, jogarão gasolina e o queimarão vivo. Estamos pedindo ajuda. 0 senhor contribuiria?

- Quanto estão dando em média?

- Ah, entre 5 e 10 litros.

Feitas as devidas considerações sobre as intenções humorísticas de "N", ao término da piada o mecanismo cognitivo de processamento do ouvinte "O" busca uma solução para resolver a aparente incongruência gerada pelo punchline; afinal de contas, do ponto psico-cognitivo-sociocultural, há uma "incoerência" entre a pergunta do motorista - que carrega tacitamente a força de um ato ilocutório de predisposição em contribuir com a campanha - e a resposta "entre 5 e 10 litros" do guarda de trânsito. De acordo com o Princípio de Relevância, para rir da piada o mecanismo dedutivo do ouvinte/leitor "O" deve selecionar, dentre algumas suposições relevantes, a mais relevante para o caso, tal que esta resolva o problema da aparente incoerência ontológica. Nesse plano, a interpretação da piada, e em consequência o riso, se caracteriza pelo reconhecimento " $\mathrm{x}$ " que o ouvinte " $\mathrm{O}$ " deve fazer do punchline.

A implicação contextual gerada pelo punchline dessa piada, e à qual o ouvinte " $O$ " deve chegar, é que, se depender do guarda e dos outros motoristas que já colaboraram com a campanha, o prefeito será queimado vivo. Isso é o "x" contido na intenção informativa "I" que o narrador "N" tenciona tornar manifesta ao ouvinte " $\mathrm{O}$ ".
E o riso, como é gerado? De acordo com Balzano (2001, p. 78), cada vez que nos deparamos com uma situação incongruente ou experimentamos algo que não se enquadra às normas pré-estabelecidas do mundo, rimos dele. A incongruência tem a ver com a quebra da harmonia do estado de coisas do mundo. Nas piadas anteriores, é essa situação incongruente do estado de coisas que provoca o riso, pois viola as expectativas de um mundo intrinsecamente ordenado em que professoras não caem na sala de aula, secretárias não transam com executivos e não se queimam políticos vivos (ainda que alguns merecessem isso).

Em resumo, a intenção "I" do narrador "N" e a interpretação "x" feita por "O" são produtos, além do conjunto de informações contextuais internas às piadas, da capacidade que os indivíduos têm de agregar à comunicação outras tantas informações que estão fora da narração da piada, tais como crenças, valores, convenções, tabus, atitudes, estereótipos, etc. que fazem parte do conhecimento sociocultural de cada indivíduo. A intenção informativa "I" de "N" é uma ostensão, a interpretação " $\mathrm{x}$ " de "O" é uma implicatura, um passo inferencial.

Mas a relação entre humor e riso não é tão simples assim. Pode dar-se o caso em que o ouvinte elabore todo o trabalho cognitivo de interpretação da piada, mas o efeito não seja humorístico. Em Santos (2014, p. 128-130), encontramos a explicação de argumentos em favor do riso como resultado do alívio das tensões psicológicas geradas na mente do ouvinte no transcorrer da narração da piada. O punchline (final insólito) conduz o significado da piada a um sentimento de entretenimento prazeroso que o ouvinte externa no riso. 0 riso é, então, a reação física resultante do efeito de prazer do humor na piada.

Casos em que o humor não é convertido em prazer pode ser explicado na seguinte piada. 
Piada 5.

O cara fazia xixi na cama toda noite. Já estava adulto e continuava a mijar na cama. Ele sonhava que vinha um anjo e perguntava:

- Você já fez xixi?

E ele respondia:

\section{- Não!}

Não dava outra, mijava na cama.

Desolado resolveu procurar tratamento. Foi a um psicólogo e contou seu problema. 0 psicólogo aconselhou que ele devia enganar o anjo.

- Quando o anjo vier e te perguntar "você já fez xixi?" você responde "já fiz" e o teu problema fica resolvido. Ok?

- Certo.

Naquela noite o cara se preparou para enganar o anjo do sonho. E lá veio o anjo com a pergunta:

- Você já fez xixi?

E ele respondeu:

- Já!

E o anjo:

- E cocô?

Essa piada foi contada para três pessoas, sendo que duas delas caíram imediatamente na gargalhada e a outra ficou olhando fixamente o narrador sem esboçar qualquer reação humorística. 0 narrador inconformado com a falta de sensibilidade humorística da ouvinte interrogou-a se ela não havia gostado da piada ou se não a havia entendido, ao que a ouvinte respondeu que gostou e que havia sim entendido a piada. Mas o caso era que ela vivia com a mãe cadeirante que não tinha os movimentos nos membros e que ela sozinha dava banho na mãe duas vezes ao dia. 0 narrador pediu desculpas pelo equívoco e os três ficaram com a cara de tacho.
Nesse caso, a ouvinte elaborou e percorreu todo o transcurso cognitivo de interpretação da piada explicado nos parágrafos anteriores. $O$ fato de não ter rido é resultado do efeito humorístico (ou sua falta) que a piada lhe causou, uma vez que essa historieta não lhe pareceu humorística e sim representava uma evidência de sua vida cotidiana, o que não lhe causava entretenimento humorístico. Nesse caso, a piada perde a função de piada, sendo mentalmente avaliada como um discurso sério, em função de que o punchline contraria a expectativa que o ouvinte faz ao início da narração. Em efeito, o significado não é suficientemente relevante para o ouvinte avaliá-lo como capaz de provocar o efeito humorístico que esperava o narrador. Santos (2104, p. 185) ressalta que, nesse caso, a piada, como gênero textual, morre.

\section{Fechando as ideias}

Neste estudo, tomando como material de análise a piada prototípica, buscamos descrever como a linguagem humana veicula a intenção humorística. Demonstramos, ainda que rudimentarmente, que, em interações comunicativas humorísticas, a intenção, tanto de quem conta a piada quanto de quem a interpreta, faz parte do significado comunicado verbalmente e que não considerá-lo nos estudos de linguagem é insensibilizar-se com a própria interpretação comunicativa - que subjaz à interação dos indivíduos social e coletivamente.

As teorias linguísticas tradicionais por si só não dão conta de conceituar a intenção na comunicação. Como visto, interpretar, entender e mensurar a intenção humorística é uma tarefa que vai além dos estudos linguísticos tradicionais, haja vista que o conceito de intenção pertence a muitas disciplinas das ciências humanas, principalmente às relacionadas às abordagens cognitivas, tais como a pragmática, a psicologia, a filosofia da mente e a neurociência cognitiva. 
Portanto, um estudo mais aprofundado não só da intenção, mas também dos desejos, das emoções e dos sentimentos, principalmente da parte de quem interpreta, é assunto que os estudos da linguagem, tais como a pragmática, a psicologia, a filosofia da mente e a neurociência cognitiva, podem explicar.

\section{Referências}

BALZANO, Silvia. El chiste y su relación con las formas de socialización. Revista de investigaciones folclóricas, Buenos Aires, v. 16, dic. 2001.

EMEDIATO, Wander. A fórmula do texto. Rio de Janeiro: Geração Editorial, 2007.

GIL, Célia Maria Carcagnolo. Elementos essenciais da piada. In: ANTUNES, Letizia Zini (Org.). Estudos de literatura e linguística. Assis: Arte e Ciência, 1998. p. 295-318.

GRICE, Herbert Paul. Meaning. Published in Philosophical Review, v. 66, p. 377-388, 1957. St. John's College, Oxford. Disponível em: <http://web.stanford.edu/class/linguist130a/ section/grice57.pdf>. Acesso em: July 2015.

Logic and conversation. In: COLE, Peter; MORGAN, Jerry (Ed.). Syntax and semantics. New York: Academic Press, 1975. Vol. 3, p. 41-58.

MUNIZ, Kassandra da Silva. Piadas: conceituação, constituição e práticas: um estudo de um gênero. 2004, 159 f. Dissertação (Mestrado em Linguística) - Setor Instituto de Estudos Linguísticos, Universidade Estadual de Campinas. Campinas, 2006.

SANTOS, Sebastião Lourenço. $O$ enigma da piada: convergências teóricas e emergência pragmática. Ponta Grossa: Editora da UEPG, 2014.

Contexto e contextualização: quando o significado acontece. Anais eletrônicos do VII Círculo de Estudos em Linguagem (CIEL). Ponta Grossa: 2013.

SPERBER, Dan, WILSON, Deidre. Relevance: communication and cognition. Oxford: Blackwell, 1986

STRAWSON. Peter Frederik. Intention and convention in speech acts. In The Philosophical Review, v. 73, n. 4, p. 439-460, 1964. Disponível em: <https://pantherfile.uwm.edu/ hinchman/www/Strawson-Intention\&Convention.pdf>. Acesso em: ago. 2015.
YUS RAMOS, Francisco. La teoría de la relevancia y la estrategia humorística de la incongruencia-resolución. Revista Pragmalinguística. № 3-4, 1996, p. 497-509. Disponível em: <http://rua.ua.es/dspace/bitstream/10045/22937/1/Francisco_Yus_1996_ Pragmalinguistica.pdf>. Acesso em: ago. 2009.

Recebido em 05/10/2015

Aceito em 21/01/2016. 